\title{
Productivity of the forest band system on Chernozeme of the Southern steppe of the Volga Region
}

\author{
P. N. Prozdov ${ }^{1}$, D. A. Mashtakov ${ }^{1}$, and $Y u$. V. Barinov ${ }^{1, *}$ \\ ${ }^{1}$ Saratov State University named after N. I. Vavilov, 410012, Sovetskaya str., 60, Saratov, Russia
}

\begin{abstract}
The aim of the research was to study the state and productivity of Quercus robur L. when mixed with associated species - Fraxinus lanceolata L. and Acer platanoides L. in the forest band system and in forest bands reinforced with grooves for additional moisture accumulation. The investigations were carried out in the agro-forest landscapes of the steppes of the Volga Upland on the southern chernozem heavy loam with a humus content of $4.5 \%$. In many respects, the productivity of Qvercus robur L. in forest belts depends on the applied mixing scheme, the selection of the accompanying rock, and the timely agrotechnical and silvicultural care in the created forest belts. In recent decades, silvicultural care (harvesting, sanitary, and reforestory cutting) is practically not carried out due to the changed economic situation in forestry and forest melioration in Russia. Therefore, the state and productivity of forest belts with Qvercus robur L. largely depends on the choice of the accompanying tree species that will grow in the forest belt along with Qvercus robur L. Optimal matching schemes for mixing Qvercus robur L. with associated tree species allow for maximum productivity and durability of the forest belt. Studies have shown that when mixing Qvercus robur L. and Acer platanoides L. growth Qvercus robur L. in height and diameter, respectively, by $5 \%$ and $14 \%$ greater than the growth of Qvercus robur L. when mixed with Fraxinus lanceolata L. Val ditch in the forest band, absorbing additional moisture, contributes to an increase in the intensity of growth of Qvercus robur L. by 10-12\%.
\end{abstract}

\section{Introduction}

Qvercus robur L. is the most common main breed used in protective afforestation in the conditions of the chernozem steppe of the Volga Upland of Russia. This is facilitated by the high productivity of Qvercus robur L. in chernozem soils and its drought resistance, which allow to grow protective forest plantations with high taxation indices and quality, its durability and ability to sprout vegetative reproduction, allowing the forest belts to fulfill their functions for more than 100 years, the great economic value of wood Qvercus robur L. $[1,2]$. The surveys in the article reflect the problem of preserving the productivity of

\footnotetext{
*Corresponding author: yamato@ fromru.com
} 
Qvercus robur L. in forest belts by mixing Qvercus robur L. with Fraxinus lanceolata L. and Acer platanoides L.

\section{Material and methods of research}

The research was carried out in the agro-forest landscape of the Privolzhskaya Upland of the Right Bank of the Saratov Region. The experimental site is a local agro-forest landscape microsystem consisting of 13 sheltered and fast-regulating forest belts with the main breed Qvercus robur L., protecting crop rotation crops on an area of 954 hectares. The area of forest belts is 44 hectares, the protective forest cover is $4.5 \%$. The sheltered forest belts are located in the north-north-east (CER) to the south-south-west (SWN), the distance between the bands is $420 \mathrm{~m}$ (Figure 1). The soils of the experimental site-chernozem southern heavy loam weakly washed with low clay on clays.

\section{Results}

In accordance with the purpose of the research, two experiences were made:

Experience 1. Investigation of the state and productivity of Qvercus robur L. under the influence of a ditch shaft. The experiment was carried out according to the following scheme: 1. A forest belt reinforced with a ditch shaft. The main breed is Qvercus robur L., concomitant - Fraxinus lanceolata L.

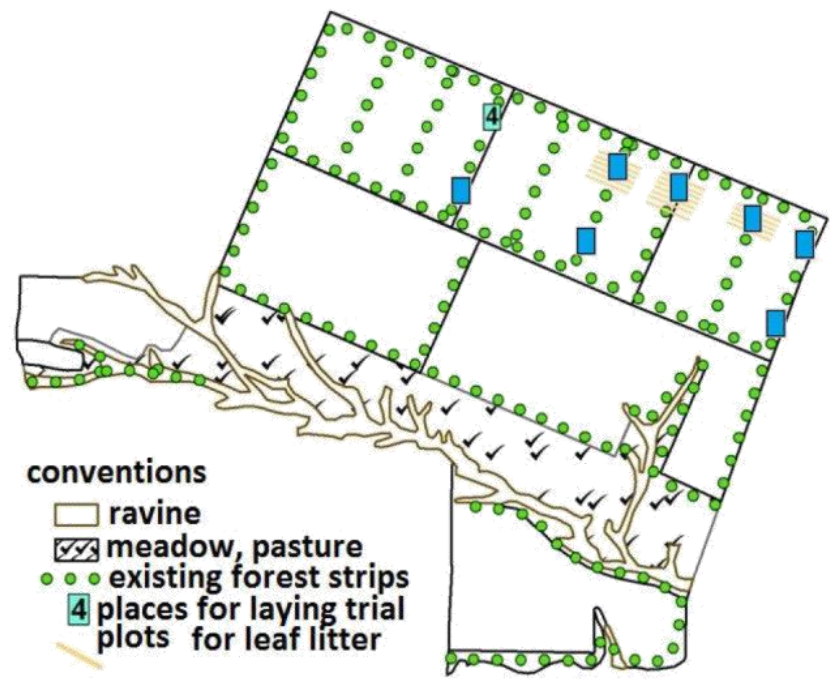

Fig. 1. Layout of the pilot site with test areas.

The age of the forest belt is 47 years. The design of the forest belt is delicate. 2. Forest belt without a ditch-tree. Control. The main breed is Qvercus robur L., concomitant Fraxinus lanceolata L. The age of the forest belt is 47 years. The design of the forest belt is delicate.

Experience 2. Investigation of the state and productivity of Qvercus robur L. when mixed with various associated rocks. The experiment was carried out according to the following scheme: 1. Forest strip with accompanying rock Fraxinus lanceolata L. The construction of the forest strip is delicate. The age of the forest belt is 42 years. 2. Forest strip with accompanying rock Acer platanoides L. The construction of the forest belt is delicate. The age of the forest belt is 42 years. In both forest belts Qvercus robur L. 
occupies three central rows, the accompanying rocks are the extreme rows. The structure of the forest is striped.

Forest meliorative characteristics of trial plots in forest belts with the main breed of Qvercus robur L. and concomitant - Fraxinus lanceolata L. and Acer platanoides L. is presented in Table 1.

Table 1. Forest reclamation characteristics of experimental forest belts in trial plots.

\begin{tabular}{|c|c|c|c|c|c|}
\hline $\begin{array}{l}\overline{0} \\
\stackrel{0}{0} \\
. \Xi\end{array}$ & \multirow{2}{*}{ Mixing scheme } & \multirow{2}{*}{ Type of fit, structure } & width, $\mathrm{M}$ & $\begin{array}{c}\text { Steepness of the } \\
\text { terrain }\end{array}$ & $\begin{array}{l}\text { Age, } \\
\text { years }\end{array}$ \\
\hline $\begin{array}{l}\overline{\bar{D}} \\
\text { छ् } \\
\text { छ }\end{array}$ & & & $\begin{array}{c}\text { Number of } \\
\text { rows }\end{array}$ & $\begin{array}{c}\text { Type of } \\
\text { silviculture } \\
\text { conditions }\end{array}$ & $\begin{array}{c}\text { Security } \\
\%\end{array}$ \\
\hline \multirow{2}{*}{1} & \multirow{2}{*}{ Fr-Qu- Qu - Qu - Fr } & \multirow{2}{*}{ Wood-shade, openwork } & 15 & $1^{0}$ & 47 \\
\hline & & & 5 & Д0-1 & 74 \\
\hline \multirow{2}{*}{2} & \multirow{2}{*}{$\mathrm{Fr}-\mathrm{Qu}-\mathrm{Qu}-\mathrm{Qu}-\mathrm{Fr}$} & \multirow{2}{*}{ Wood-shade, openwork } & 15 & $2,5^{0}$ & 47 \\
\hline & & & 5 & Д $_{1-2}$ & 88 \\
\hline \multirow[b]{2}{*}{3} & \multirow{2}{*}{$\mathrm{Ac}-\mathrm{Qu}-\mathrm{Qu}-\mathrm{Qu}-\mathrm{Ac}$} & \multirow{2}{*}{ Wood-shade, openwork } & 15 & $0,2^{0}$ & 42 \\
\hline & & & 5 & Д0-1 & 35 \\
\hline \multirow[b]{2}{*}{4} & \multirow{2}{*}{$A c-Q u-Q u-Q u-A c$} & \multirow{2}{*}{ Wood-shade, openwork } & 15 & $2^{0}$ & 42 \\
\hline & & & 5 & Д $1-2$ & 44 \\
\hline
\end{tabular}

The studies were carried out by the trial area method (PP), generally accepted in forest inventory and forest melioration $[3,4]$. When laying trial plots, the entire cycle of placement and mixing was covered, and the complete scheme of mixing of tree species in forest belts was reflected. The size of each trial plot is $200-400 \mathrm{~m} 2$. Trial areas were laid in triplicate, allowing to obtain the necessary data for statistical processing. On the trial plots, measurements were made: heights - an altimeter for every fifth tree, a diameter - at an altitude of $1.3 \mathrm{~m}$ for each tree. The preservation of rocks was determined by the percentage of surviving trees to the number of planted. The closeness was determined by the eye-toeye ratio of the area of the projection of tree crowns to the area occupied by the plantation. The openness of the forest belts was determined by the number of through gaps and permeability [5].

The results of the studies were subjected to statistical processing using the applied computer programs Statistica and Excel [6].

Productivity of cambium (PC) - as the ratio of wood growth by volume over a year or period of years to the surface area of cambial tissue [7] is calculated using a mathematical model:

$$
\mathrm{PC}=1.68 \mathrm{x}+3.65 \mathrm{z}-0.05 \text {, }
$$

where PC is productivity of cambium, $\mathrm{dm}^{3} / \mathrm{m}^{2}$; $\mathrm{x}$ is the average increment in height, $\mathrm{m} ; \mathrm{z}$ is the average increment in diameter.

The study of the relationship between tree species in forest belts and the life stability of forest belts was carried out according to the method of K. K. Vysotsky [8], with the help of which the following quantitative indicators were determined: a) the index of growth intensity (ПНР) - the ratio of the height of the tree to the cross-sectional area at chest height; b) the coefficient of competitive relations (CCO) - the ratio of the growth rate of the rock, which has the best growth (the smallest PPR) to the growth intensity of each other breed in the same plantation; c) degree of plantation sustainability (SIN) - the ratio of the actual sum of the coefficients of competitive relations to the maximum possible.

The indicator of growth intensity was determined by the formula: 


$$
\Pi H P=\frac{H \times 100}{G_{1,3}}
$$

where: ПНР - an indicator of growth intensity $\left(\mathrm{cm} / \mathrm{cm}^{2}\right) ; \mathrm{H}$ is the height of the tree species, m; G1.3 - the cross-sectional area of the tree species at an altitude of $1.3 \mathrm{~m}, \mathrm{~cm}^{2}$.

\section{Discussion of results}

When growing protective forest plantations, the problem of providing wood with moisture under conditions of its deficiency is becoming increasingly acute. Deficiency of moisture during the cultivation of forest belts in the arid conditions of the Volga region can be replenished by the creation of hydraulic structures. The creation of trench trees in forest belts improves the growth and development of tree species, increases the survival rate, biological productivity of forest belts, increases durability, extends the range of used trees and shrubs [9].

When studying the influence of the shaft-ditch on the growth and condition of tree species, studies were carried out in the forest belt with Qvercus robur L. and Fraxinus lanceolata $\mathrm{L}$. The results of the studies are shown in Table 2 . When analyzing the efficiency of a forest belt reinforced by a ditch groove (the steepness of the slope is $2.5 \mathrm{o}$ SE, the test area 2 (PP 2) and PP 3 is without a ditch as a control), the best taxation indicators for height, reserve, bonitet at the forest belt in the upper part of the shaft, while maintaining the trend in 2002 and 2015. (table 2).

Qvercus robur L. and Fraxinus lanceolata L. at the age of 35 years in a forest belt reinforced by a ditch groove correspond to class II in bonitet, and in the forest belt without a ditch-tree III. By the age of 47, there is a leveling in bonitet rocks with some preponderance in the forest belt with a ditch-shaft. The same dynamics is maintained for the stock.

Table 2. Forestry-taxation indicators of forest belts with ditches in the steppes of the Volga region (1967-2015).

\begin{tabular}{|c|c|c|c|c|c|c|c|c|c|}
\hline \multirow[b]{2}{*}{ 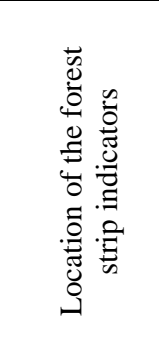 } & \multirow[b]{2}{*}{ 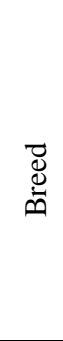 } & \multicolumn{2}{|c|}{ Medium } & \multirow[b]{2}{*}{ 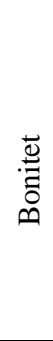 } & \multirow{2}{*}{ 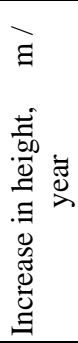 } & \multirow{2}{*}{ 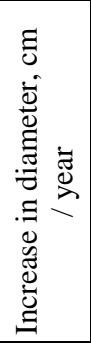 } & \multirow[b]{2}{*}{ 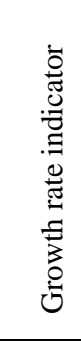 } & \multirow[b]{2}{*}{ 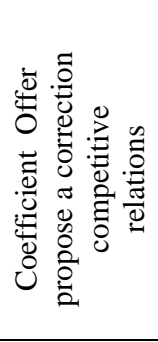 } & \multirow[b]{2}{*}{ 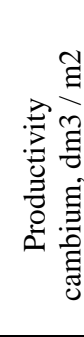 } \\
\hline & & 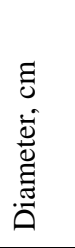 & $\begin{array}{l}\Xi \\
\overrightarrow{0} \\
\frac{.00}{\overrightarrow{0}} \\
\text { I }\end{array}$ & & & & & & \\
\hline $\begin{array}{l}\text { Forest belt } \\
\text { with a shaft } \\
\text { - ditch }\end{array}$ & $\mathrm{Qu}$ & $\frac{10,6}{13,8}$ & $\frac{11,0}{13,6}$ & $\frac{\text { II }}{\text { III }}$ & $\frac{0,31}{0,29}$ & $\frac{0,30}{0,29}$ & $\frac{1,25}{0,91}$ & $\underline{0,72}$ & $\frac{1,57}{1,50}$ \\
\hline $\begin{array}{c}\text { Лп+ shaft - } \\
\text { ditch }\end{array}$ & $\mathrm{Fr}$ & $\frac{9,0}{12,9}$ & $\frac{11,0}{13,5}$ & $\underline{\text { II }}$ & $\frac{0,31}{0,29}$ & $\frac{0,26}{0,27}$ & $\frac{1,73}{1,03}$ & 0,88 & $\frac{1,42}{1,43}$ \\
\hline $\begin{array}{c}\text { Лп } \\
\text { without } \\
\text { shaft }\end{array}$ & $\mathrm{Qu}$ & $\begin{array}{l}\frac{9,4}{12,2} \\
\frac{8,2}{10,9}\end{array}$ & $\frac{10,0}{13,0}$ & $\underline{\mathrm{III}}$ & $\frac{0,28}{0,28}$ & $\frac{0,27}{0,26}$ & $\frac{1,44}{1,11}$ & $\frac{0,75}{0,84}$ & $\frac{1,40}{1,30}$ \\
\hline
\end{tabular}




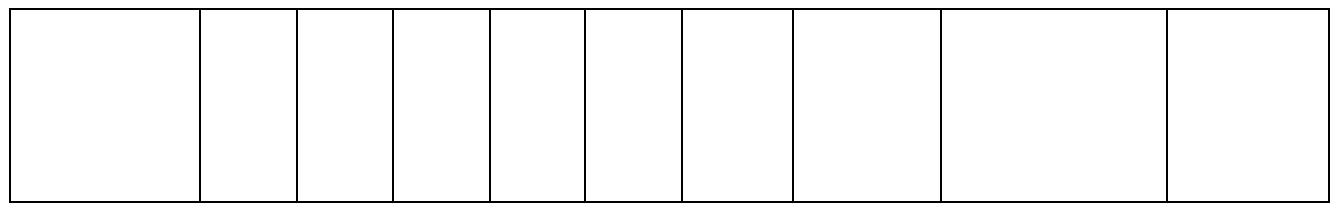

Note 1. - Forest belt with Qvercus robur L. and Fraxinus lanceolata L. Numerator 2002 (age 35 years); Denominator - 2015 (age - 47 years); Qu-Qvercus robur L.; Fr Fraxinus lanceolata L.

The indicator of growth intensity tends to decrease, both under the influence of truncated ditches and with the age of rocks, which confirms the best taxation parameters. The coefficient of competitive relations and the productivity of the cambium indicate the correctness of the choice of wood species and the mixing scheme (Table 2).

An analysis of the growth path along the height of model trees allowed us to choose from the well-known growth functions the A. Micherliha equation, which became the basis for calculating mathematical models. The graph represents a curved line starting from the origin and approaching the asymptote of the parallel axis of abscissas with age (Figure 2).

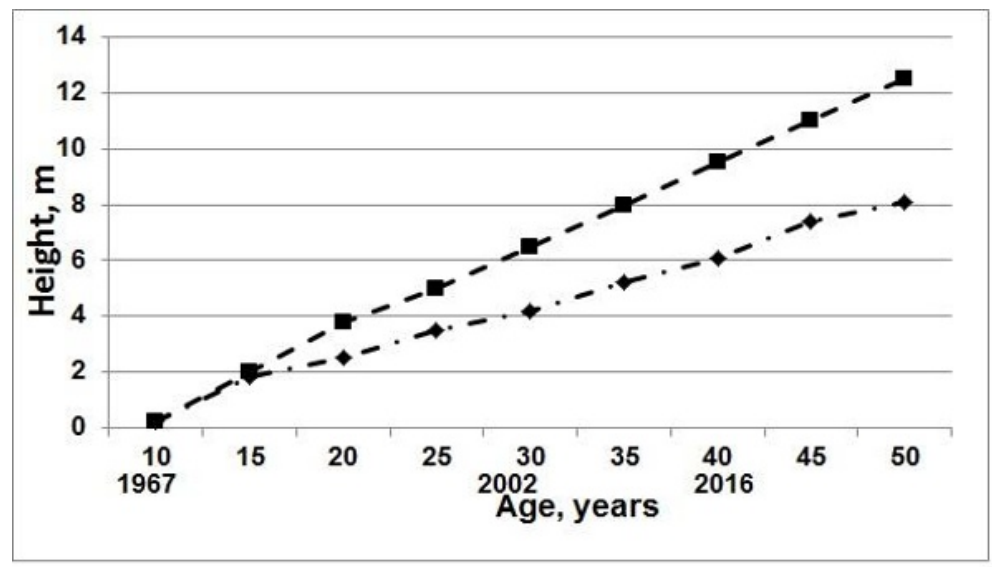

Fig. 2. Growth in the height of Quercus robur L. under the influence of a ditch shaft.

The calculated mathematical model is represented by a regression equation of the general form:

$$
H=b_{0}\left(1-e^{-b 1 A}\right)^{b 2} \text {, }
$$

where $\mathrm{H}$ is the height of Qvercus robur L., $\mathrm{m}$; b0 - a parameter characterizing the maximum value of the height of Qvercus robur L.; A - age, years; e is the base of the natural logarithm; b1, b2 - model parameters.

$$
\begin{gathered}
H_{B}=27,52\left(1-e^{-0,0331}\right)^{1,488,} \\
H_{K}=19,89\left(1-e^{-0,0159}\right)^{0,815,}
\end{gathered}
$$

where $\mathrm{H}_{\mathrm{B}}, \mathrm{H}_{\mathrm{K}}$ - accordingly height Qvercus robur L. (m) in forest belts in the upper part of the shaft and on the control.

The coefficient of determination for the three regression equations is 0.99 .

Thus, the studies carried out in the experiment 1 proved the positive influence of the ditch-tree on the growth, productivity and state of Qvercus robur L., as evidenced by the data of the Qvercus robur L. taxation indices in the version with a barked and control shaft presented in Table 2 and Figure 2. 
In experiment 2, a study was made of the effect of various accompanying tree species used in forest bands on the growth, condition, and productivity of Qvercus robur L. The results of the studies are shown in Figure 3.

Growth of Qvercus robur L. in height, when it was mixed with a maple leaf, began to exceed the height of Qvercus robur L. when it was mixed with Fraxinus lanceolata L., since the age of 3 years Qvercus robur L. (Figure 3).
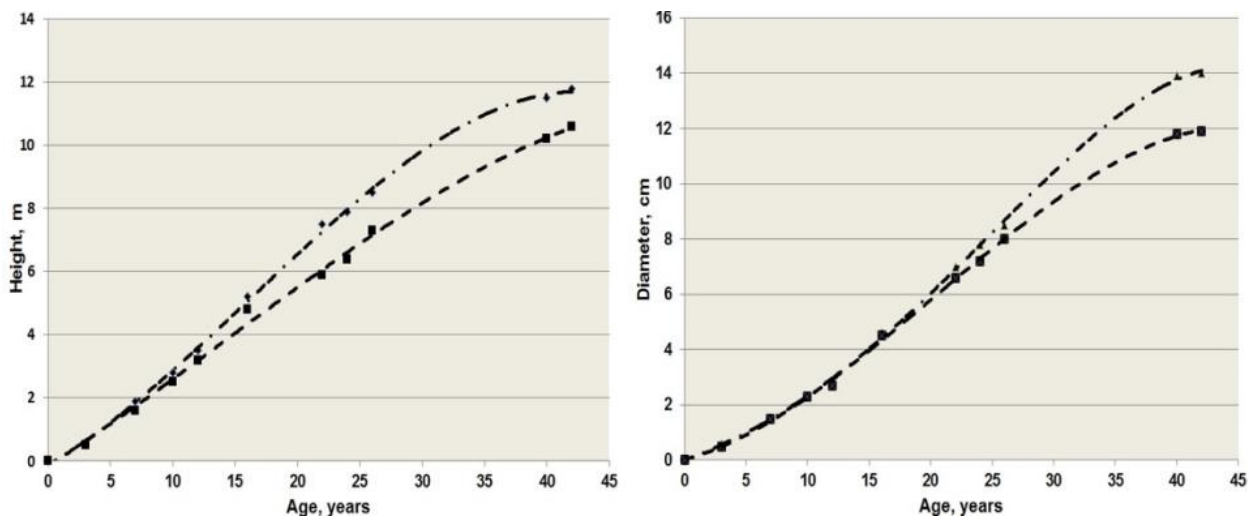

Fig. 3. Height growth and diameter of Qvercus robur L. when mixed with Acer platanoides L. (hatch) and Fraxinus lanceolata L. (bar-dotted line).

$$
\begin{gathered}
H_{A 1}, M=-0,102+0,236 x+0,008 x^{2}-0,0002 x^{3}, \\
H_{A 2}, M=0,003+0,100 x+0,02 x^{2}-0,0006 x^{3}+4,5085 E-6 x^{4},
\end{gathered}
$$

where $\mathrm{H}_{д 1}$ and $\mathrm{H}_{д 2}$ - the height of Qvercus robur L. when mixed with Acer platanoides L. and Fraxinus lanceolata L., respectively, $\mathrm{m} ; \mathrm{x}$ - age, years.

The coefficient of determination for the regression equations is 0.98 and 0.96 , which shows a high correlation between height and age.

A similar trend is the excess of the average diameter of Qvercus robur L., when mixed with Acer platanoides L., compared to Fraxinus lanceolata L., is shown in Figure 3. The difference in Qvercus robur L. diameters when mixed with Acer platanoides L. and Fraxinus lanceolata L. begins to be traced from the age of 20 and reaches a maximum $(2 \mathrm{~cm}$ or $14 \%$ ) at the age of 42 years. The regression analysis made it possible to obtain polynomial equations for the growth course of Qvercus robur L. in terms of diameter in mixing with Acer platanoides L. $\left(D_{д_{1}}\right)$ and Fraxinus lanceolata L. $\left(D_{д_{2}}\right)$ :

$$
\begin{aligned}
& D_{\text {д1 }}, \text { См }=-0,072+0,145 x+0,011 x^{2}-0,0002 x^{3}, \\
& D_{\text {д2 }}, \mathrm{CM}=-0,077+0,170 x+0,010 x^{2}-0,0002 x^{3},
\end{aligned}
$$

where - D д1 and D д1 - Qvercus robur L. when mixed with Acer platanoides L. and Fraxinus lanceolata L., respectively, cm; x - age, years.

The coefficient of determination for the regression equations is 0.99 , which shows a high correlation between diameter and age.

\section{Conclusions}

As a result of our studies, we made the following conclusions:

- Application of a ditch-tree in a 47-year-old forest belt for the conditions of the steppe of the Volga Upland of Russia allows to increase the quality of Qvercus robur L. from the III class of bonitet to class II of bonitet; 
- The height of Qvercus robur L. in the band strengthened by the ditch groove exceeded the height of Qvercus robur L. by $4.5-10 \%$ in control, and the diameter by $11-12 \%$;

- The indicator of the growth intensity of Qvercus robur L. (PNR) is reduced by $14-18 \%$ in the forest belt with a ditch-shaft compared to the control, which indicates the best performance indicators of Qvercus robur L. in the forest belt with a ditch-shaft and as a consequence better growing conditions for Qvercus robur L.;

- When Qvercus robur L. was mixed with Acer platanoides L., the growth in height of Qvercus robur L. during the whole period of life was noted by $4-5 \%$ and diameter - by $14 \%$ more than the growth of Qvercus robur L. when mixed with Fraxinus lanceolata L.;

- The regression analysis allowed to obtain the equations of the dependence of the growth course of Qvercus robur L. in the forest belt, strengthened by the ditch groove and without it, as well as by mixing Qvercus robur L. with Acer platanoides L. and Fraxinus lanceolata L. The resulted determination coefficients show a high level connection between the traits being studied.

Thus, the obtained results of the studies revealed regularities in increasing the productivity of Qvercus robur L., increasing its taxation indicators in those forest belts where ditch-trees are used to collect additional moisture and where Acer platanoides L is used as a companion breed. However, such results can be reliable for conditions of the steppe zone of the Volga Upland of Russia. In other natural zones and for other tree species, the results of the research may be different, therefore, research should be continued for other tree species and other natural areas of Russia.

The work was prepared with the support of the Ministry of Education and Science of the Russian Federation.

\section{References}

1. D. A. Mashtakov, N. G. Berlin, P. N. Proezdov, V. V. Dubrovin, Scientific Life, 6 (2015).

2. N. G. Berlin, S. V. Kabanov, D. A. Mashtakov, Bulletin of the Altai State Agrarian University, 5 (2015)

3. V. P. Ogievsky, A. A. Hirov, Research and study of forest cultures (Forest industry, Moscow, 1964)

4. GOST 56-69-83 "Testing forest areas. Bookmark Method” (Moscow, 1983)

5. Methodology of system studies of forest landscape landscapes (VASKhNIL, VNIALMI, Moscow, 1985)

6. B. A. Dospekhov, Methods of field experiment (Moscow, 1985)

7. S. S. Pyatnitsky, Vegetative Forest (Moscow, 1963)

8. G. N. Vysotsky, Selected Works (Moscow, 1962)

9. P. N. Proezdov, D. A. Mashtakov, A. V. Panfilov, Niva of the Volga Region, 2 (2017) 